\title{
심장성 쇼크
}

\author{
조성규· 이상윤 ${ }^{1}$
}

서울대학교 의과대학 흥부외과학교실, ${ }^{1}$ 소아과학교실

\section{Cardiogenic shock}

\author{
Sungkyu Cho, Sang-Yun Lee ${ }^{1}$ \\ Departments of Thoracic and Cardiovascular Surgery and 'Pediatrics, \\ Seoul National University College of Medicine, Seoul, Korea
}

Cardiogenic shock is an acute circulatory failure due to compromised myocardial contractility associated with congenital heart diseases and cardiomyopathies, such as myocarditis. In this article, the authors present a 3-step overview of cardiogenic shock diagnosis and management to restore tissue oxygen delivery. The first step is early recognition of nonspecific signs of the shock. The second step is medical management, monitoring, and repeated assessment. In addition to conventional parameters, biomarkers may be useful to monitor the shock. The final step is mechanical circulatory support, such as ventricular assist devices, for children with the refractory shock. We also briefly describe the shock in multisystem inflammatory syndrome in children with coronavirus disease 2019.

Key words: Cardiovascular System; Child; Extracorporeal Membrane Oxygenation; Heart-Assist Devices; Shock, Cardiogenic

\section{서 론}

쇼크는 전신 조직 관류가 현저히 감소하여 조직 산소공 급이 감소하는 병리적 상태이다. 조직 내 산소공급이 부족 하면, 정상적 산소대사를 유지할 수 없어 비효율적 무산소 대사가 진행된다. 쇼크의 진행에 따라, 조직 내 산소 추출 을 이용한 보상 기전의 한계를 초과하여 임상적 악화 및 젖산산증이 발생한담. 쇼크가 지속하면 혈관 반응, 염증,

\section{Received: Nov 4, $2020 \quad$ Revised: Dec 9, 2020}

Accepted: Dec 10, 2020

\section{Corresponding author}

Sang-Yun Lee (ORCID 0000-0002-3071-2661)

Department of Pediatrics, Seoul National University College of Medicine, 101 Daehak-ro, Jongno-gu, Seoul 03080, Korea

Tel: +82-2-2072-4064 Fax: +82-2-743-3455

E-mail: saeng123@hanmail.net
대사 변화, 세포 반응, 내분비 및 전신 반응과 같은 생리학 적 변화 및 불안정성이 나타난다. 부족한 산소공급에 대한 보상의 하나로 특정 기관의 혈류를 감소시켜 뇌, 심장, 신 장, 간과 같은 주요 기관의 산소공급을 유지하려고 한다. 쇼크의 원인과 관계없이 쇼크에 대한 환자의 반응 패턴, 병태생리, 임상 증상 및 치료에 대한 반응은 환자의 임상 상황 및 생물학적 반응에 따라 다를 수 있다.

일반적으로, 쇼크는 저혈량성, 심장성, 분포(distributive), 폐쇄(obstructive), 패혈 쇼크의 5 가지 유형으로 분류할 수 있다. 소아에서는 주로, 선천심장병 또는 급성 심근염을 포함한 심근병증 환자에서 심장성 쇼크가 발생 한다 ${ }^{2)}$.

Coronavirus disease 2019 (COVID-19) 대유행(범 유행) 시대에 중증급성호흡기증후군 코로나바이러스 2 (severe acute respiratory syndrome-coronavirus 2 , SARS-CoV-2)에 의한 소아 다기관염증증후군(multisystem inflammatory syndrome in children, 
MIS-C) 환자에서 심혈관질환이 보고되고 있다 ${ }^{3)}$ MIS-C 환자는 열, 위장관 및 호흡계 증상, 쇼크를 보일 수 있으 며, 심실 기능장애, 관상동맥 확장 또는 동맥류, 부정맥 등 이 높은 빈도로 보고되고 있다.4.

따라서, 본 종설에서는 소아 심장성 쇼크의 임상증상, 진단 및 치료를 고찰하고, 치료 원칙 및 새로운 치료법인 심실보조장치(ventricular assist device, VAD)에 대해 시의적절하게 언급하고자 한다.

\section{본 론}

\section{1. 역학}

소아에서 역학에 대한 자료는 제한적이다. 넬슨 소아과 학 21판에 따르면, 선진국에서 성인을 포함한 입원 환자의 약 $2 \%$ 에서 쇼크가 발생하며, 사망률은 원인과 임상 상황 에 따라 다르다.5. 사망은 대개 급성 저혈압 쇼크 단계보다 관련 합병증 및 다발장기부전(multi-organ failure)에 기인한다6). 임상 보고에 따르면, 소아 쇼크의 흔한 원인은 심한 설사로 인한 저혈량, 외상성 출혈, 패혈증 등이다. 심 장성 쇼크는 소아응급실에서 진단된 쇼크의 5\%-17\%를 차지하고 ${ }^{7,8)}$, 그 원인은 Table 1에 나열했다.,10).

심장성 쇼크는 심장질환 및 외상(예: 선천심장병, 심근 염 및 심근병증, 심근 타박상, 심근 허혈, 부정맥)에 의한
펌프 부전(pump failure)으로 인해 발생한다. 또한 전통 적 원인 외에도 COVID-19와 같은 감염병도 이를 유발할 수 있다.

COVID-19 대유행 시기에 MIS-C가 유럽, 아메리카, 아시아에서 보고되고 있다 ${ }^{11,12)}$. 이 환자 중 일부는 쇼크 및 다발장기부전으로 중환자실 치료가 필요하거나, 가와사키 병 또는 가와사키병 쇼크증후군(Kawasaki disease shock syndrome)과 유사한 임상증상을 보였다 ${ }^{4,13)}$.

\section{2. 병태생리}

심장성 쇼크는 심장의 펌프 부전, 즉 수축 기능 및 심박 출량 감소에 의해 발생한다. 조직 산소공급을 결정하는 요 소에는 혈류량, 혈류량과 대사 요구량 사이의 균형, 산소 함유량(oxygen content)이 포함된다. 감소한 혈류를 보 상하기 위한 생리학적 변수에는 일회박출량 및 심박수가 포함되고, 일회박출량은 전부하, 심근수축력, 후부하가 결 정한다.

세포 저산소증(cellular hypoxia)은 조직 관류저하, 산 소공급 감소, 산소 소비 증가 또는 부적절한 사용으로 인 해 발생하고, 세포막 이온펌프 기능장애, 세포 내 부종, 세 포액의 세포 외 공간 누출 및 세포 내 $\mathrm{pH}$ 의 부적절한 조 절을 유발한다 ${ }^{14,15)}$. 이 상태가 지속하면 생화학적 변화가 전신으로 진행되어 대사산증 및 혈관내피 기능장애를 유 발할 뿐만 아니라, 염증 및 항염증 연쇄반응으로 이어진다 ${ }^{16)}$.

Table 1. Etiology of cardiogenic shock and heart failure

\begin{tabular}{ll}
\hline \multicolumn{1}{c}{ Structural heart disease } & \multicolumn{1}{c}{ Structurally normal heart } \\
\hline Volume overload & Cardiomyopathy (primary) \\
$\begin{array}{l}\text { Left-to-right shunt (VSD, AVSD, PDA, TA, AP window, } \\
\text { and large AP collaterals) }\end{array}$ & Dilated, hypertrophic, and restrictive \\
Pressure overload & Cardiomyopathy (secondary) \\
Severe or critical aortic stenosis & Infectious or inflammatory (myocarditis and endocarditis) \\
Aortic arch obstruction (coarctation or interruption) & Ischemia (KD and other forms of coronary artery disease) \\
Valvular dysfunction & Chronic volume overload (acquired valvular dysfunction and RHDs) \\
Atrioventricular valve insufficiency & Chronic arrhythmia \\
(AVSD and Ebstein anomaly) & \\
Semilunar valve insufficiency & Toxins (anthracyclines and radiation) \\
Aortic insufficiency after valvotomy & Muscular dystrophy \\
Truncal valve regurgitation & Metabolic disorders \\
Tetralogy with absent pulmonary valve & NA \\
Complex (single ventricle) & NA \\
Myocardial dysfunction (ischemia, congenital coronary & NA \\
anomalies, asphyxia-related, and postoperative) & \\
\hline
\end{tabular}

VSD: ventricular septal defect, AVSD: atrioventricular septal defect, PDA: patent ductus arteriosus, TA: truncus arteriosus, AP: aortopulmonary, KD: Kawasaki disease, RHD: rheumatic heart disease. 
이 일련의 과정이 복합적으로 작용하여, 조직 관류가 더 감소한다 ${ }^{16,17)}$.

쇼크의 초기 단계에는 다양한 보상 기전이 혈압, 조직 관류, 산소공급을 유지한다. 심혈관계 효과에는 교감신경 계 활성화 및 신경호르몬 조절을 통한 심박수, 심박출량, 혈관긴장도 증가가 있다. 호흡 보상은 대사산증에 대한 반 응으로, 이산화탄소 배출 촉진과 부족한 조직 관류로 인한 이산화탄소 생산 증가와 연관된다. 정상 체내 $\mathrm{pH}$ 를 유지 하기 위해, 수소이온의 신장 배설 및 중탄산염 저류가 증 가한다. 레닌-안지오텐신-알도스테론계 및 심방나트륨뇨 배설인자 축(atrial natriuretic factor axes), 코티솔 및 카테콜아민 합성 및 분비, 항이뇨호르몬 분비를 통한 나트륨 조절을 통해 혈관 내 용적을 유지하려 한다. 이러 한 보상 기전에도 불구하고, 기저의 쇼크 및 신체의 반응 으로 인해 혈관내피 손상으로 인해 혈관내액(intravascular fluid)이 세포 외 공간으로 누출된다. 쇼크의 다른 중요한 초기 병태생리는 일회박출량에 미치는 영향이다. 모든 형태의 쇼크에서 심박수, 전부하, 심근수축력, 후부 하의 변화가 개별적으로, 또는 조합되어, 일회박출량에 영 향을 준다. 쇼크에 대한 주요 보상 기전은 체액 손실 및 전 부하 감소에 대해 심박수 및 말초혈관저항을 증가시키는 것으로, 이는 심박출량 및 전신 혈압을 유지하기 위한 초 기 기전이다. 만약 적절한 체액 보충이 없다면, 저혈압 및 조직 허혈이 발생하고 임상적으로 악화한다. 이 상태에서 추가로 삼투압이 낮으면, 내피 손상 및 모세혈관 누출로 인해 더 많은 체액 손실 및 쇼크 악화가 발생한다. 쇼크의 보상 기전에 의해 빈맥, 호흡곤란, 안절부절, 발한, 대사산 증, 저혈압, 핍뇨, 차고 축축한 피부를 포함한 장기부전의 임상소견이 나타난다. 장기부전의 임상증상은 일반적으로 심각한 병태생리학적 변화에 의해 발생한다. 심장성 쇼크 에서는 심장박출지수가 상당히 감소한 후, 임상증상이 발 생한다 ${ }^{2,18)}$.

\section{3. 심부전 및 심장성 쇼크의 진단 및 치료 원칙}

\section{1) 쇼크의 인지}

심장성 쇼크를 치료하려면 조기에 인지하는 것이 중요 하다. 여기에 유용한 비특이적 증상으로, 초기에 빈호흡을 동반하지 않은 빈맥, 진행된 상태에서의 핍뇨, 말초 관류 저하, 호흡 곤란 또는 부전, 의식상태 변화, 저혈압을 들 수 있다(Table 2) ${ }^{19)}$. 흔히 임상의가 저혈압을 근거로 쇼크 여부를 판단해야 한다고 오해한다. 하지만, 저혈압은 초기 에 혈압 및 말초 관류를 보존하려는 복잡한 보상 기전으로 인해 나타나지 않는 경우가 많으므로, 진단 기준에 포함되
지 않는다. 저혈압은 보상되지 않은 쇼크(decompensated shock)를 시사하며 사망과 연관된다.

\section{2) 쇼크의 분류}

심부전과 심장성 쇼크는 정맥울혈(충만압 증가로 인한) 유무와 관류저하(심박출량 또는 심근수축력 감소) 유무에 따라 분류할 수 있다이. 정맥 울혈이 있으면 '습성(wet)', 없으면 '건성(dry)'으로, 관류저하가 있으면 '차가운 (cold)', 없으면 '따뜻한(warm)' 으로 각각 분류한다. 습 성 쇼크는 폐부종, 간비대, 복수, 경정맥 팽창, S3 말굽심 음, 수포음을 보일 수 있다. 차가운 쇼크는 차가운 사지, 약하고 좁은 맥압, 모세혈관충전시간 지연, 의식 변화, 저 혈압을 보일 수 있다2,211.

\section{3) 쇼크의 진단}

쇼크의 진단은 주요 임상증상인 빈맥, 조직 관류저하, 핍뇨 및 의식 변화 정도를 고려하여 이뤄진다. 저혈압 또 는 조직 관류저하 및 고젖산혈증(hyperlactatemia) 외에

Table 2. Clinical manifestations of cardiogenic shock

\begin{tabular}{|c|c|}
\hline Variable & Manifestation \\
\hline General & Lethargy, pallor, and sweating \\
\hline \multirow[t]{4}{*}{ Hemodynamics } & Tachycardia and edema \\
\hline & Heart murmur and gallop rhythm \\
\hline & Bradycardia and arrhythmia \\
\hline & Jugular vein distention \\
\hline Respiratory & Tachypnea or bradypnea and crackles \\
\hline Nephology & Oliguria or anuria \\
\hline \multirow[t]{2}{*}{ Neurology } & Anxiety and restlessness \\
\hline & $\begin{array}{l}\text { Confusion, drowsiness, convulsion, } \\
\text { and coma }\end{array}$ \\
\hline \multirow[t]{3}{*}{ Gastroenterology } & Hepatomegaly \\
\hline & Decreased transit \\
\hline & Nausea, vomiting \\
\hline \multirow[t]{2}{*}{ Extremity } & Cyanosis of extremities or perioral area \\
\hline & Weak pulse \\
\hline Oxygen saturation & $\geq 94 \%$ on room air \\
\hline Heart rate & Appropriate for age \\
\hline Capillary refill time & $\leq 2 \mathrm{sec}$ \\
\hline $\begin{array}{l}\text { Skin color and } \\
\text { mucous membrane }\end{array}$ & Normal \\
\hline Blood pressure & Within normal range for age \\
\hline $\begin{array}{l}\text { Level of } \\
\text { consciousness }\end{array}$ & Respond more appropriately \\
\hline Biomarker & $\begin{array}{l}\text { Lactate, troponin, and central venous } \\
\text { oxygen saturation }\end{array}$ \\
\hline
\end{tabular}


도, 심박출량, 말초혈관저항, 혼합정맥혈 산소포화도, 활 력징후 측정이 진단에 유용하다 ${ }^{22}$. 혈압이 정상이라도 보 상 빈맥 및 말초혈관 수축이 있으면 쇼크를 의심해야 한 다. 임상증상이 쇼크의 원인 및 단계에 따라 다양하므로, 한 가지 변수만으로 진단하거나 치료 방침을 결정하기 어 렵다. 다만, 저혈압, 빈맥, 핍뇨, 의식상태 변화, 빈호흡, 차고 축축한 피부, 대사산증, 고젖산혈증 등이 있다면, 쇼 크를 강하게 의심해야 한다1).

\section{4) 쇼크의 치료 및 감시}

치료 목표는 정상 심박수 및 관류압(perfusion pressure) 회복, 기저 질환 호전, 주요 장기의 지속적 허혈 예 방이다 ${ }^{5}$. 정상 상태라면 교감신경계 항진을 통해 심근수축 력 및 심박수를 늘림으로써 심박출량을 증가시켜 허혈을 개선할 수 있다 ${ }^{23)}$. 하지만 심근수축력이 감소한 상황에서 는, 심박수를 늘리거나, Frank-Starling 법칙을 통해 심 실충만압(ventricular filling pressure, 전부하) 증가 또는 말초혈관저항(후부하) 감소를 통해 심박출량을 개선 할 수 있다 ${ }^{24,25)}$. 최적의 심실충만압은 환기 지원(ventilator support) 및 복강 내 압력을 포함한 심장 외 요인에 따라 달라진다. 특히, 심장수술 후 또는 제한심근병증, 비 대심근병증 환자에서 적절한 심실충만압이 일반 환자와 다를 수 있다. 심장성 쇼크 환자에서 수액요법은 임상적으 로 전부하 부족을 확인 후 투여해야 하며, 이 과정에 심초 음파검사가 유용하다 ${ }^{2}$. 주의 깊은 수액요법에도 심박출량 이 개선되지 않으면, 비정상적 심근수축력 또는 비정상적 으로 높은 후부하가 낮은 심박출량의 원인일 수 있다. 심 박수 증가를 통해 심박출량을 개선하려고 시도할 수 있다. 그러나 지나친 심박수 증가는 심실충만을 위한 확장기를 단축함으로써, 오히려 심박출량이 감소하고 심근 산소요 구량이 늘어나 심근의 산소 요구 및 공급 균형에 부정적 결과를 초래할 수 있으므로 주의해야 한다.

심장성 쇼크 환자는 초기부터 감시를 지속해야 한다. 심박 수, 수축기 및 평균 혈압, 소변량, 중심정맥압, 중심 및 혼합 정맥혈 산소포화도, 젖산, 심박출량 등이 감시 대상이다.1.

쇼크의 진단, 감시, 예후 예측을 위한 생물표지자 개발 에 많은 관심이 있었다. 좋은 표지자는 객관적으로 환자 상태를 측정하고, 치료 반응을 감시하며, 예후를 예측할 수 있어야 한다 ${ }^{26}$. 심부전 및 심장성 쇼크를 위한 주요 표 지자로, 혈중 젖산, 심근효소 및 뇌나트륨배설펩타이드가 알려졌다. 젖산은 전체 조직산소결핍증(histanoxia) 및 무산소대사를 측정하는 지표로, 사망 예측에 유용하고 2$3 \mathrm{mmol} / \mathrm{L}$ 를 치료의 목표로 한다 ${ }^{27,28)}$. 심근효소 중에서 크레아틴인산화효소MB동종효소는 도움이 되지 않지만,
트로포닌은 심근 손상 정도 및 치료 반응 평가에 유용하다 고 알려졌다 ${ }^{29}$. 뇌나트륨배설펩타이드는 돼지의 뇌에서 처 음으로 확인한 표지자로, 심방 및 심실 근육에서 합성된 다. 좌심실 확장말기압력(end-diastolic pressure) 증가 및 심장 벽 스트레스 증가로 인한 심근 늘임(myocardial stretching)은 뇌나트륨배설펩타이드 유전자의 전사를 촉진하는 것으로 알려졌다이. 소아 심장성 쇼크에서 이 펩 타이드의 예후 예측 성적은 아직 입증되지 않았지만 ${ }^{31}$, 심 근병증이 있던 환자에서는 심장기능 평가를 위한 효과가 입증되어, 이 목적으로 소아 심장성 쇼크 환자에서 사용하 고 있달.

쇼크의 원인에 대한 치료가 시작되고 저산소증 및 대사 산증이 교정되면서 일반적으로 심근수축력이 향상되지만, 수축력 감소가 지속하면 수축촉진약(inotropic drug) 투 여가 필요하다. 대표적 수축촉진약인 베타아드레날린작용 제(예: dopamine, epinephrine, dobutamine)는 수축 력 및 심박수를 늘려 궁극적으로 심박출량을 증가시킨다 (Fig. 1). 그러나, 이 중 일부는 알파아드레날린작용제 효 과를 통해 후부하를 증가시키므로, 두 효과의 균형을 신중 히 고려하여 사용한다 ${ }^{23)}$. 심장성 쇼크 환자에서 후부하가 현저히 크고 말초 관류가 불량한 경우가 많으므로, 후부하 증가가 지속하고 수축촉진약 단독 투여가 조직 관류를 개 선하지 못하면 베타아드레날린작용제와 함께 nitroprusside 또는 milrinone 등으로 후부하를 낮춰야 할 수 있 다. 특히, milrinone은 심근수축력을 늘리고 베타아드레 날린작용제와의 상승효과를 통해 심근 내 고리일인산아데 노신 농도를 높인다 ${ }^{19,32)}$.

주기적 쇼크 환자 평가와 상태에 따른 대응은 치료에 필 수적이다(Fig. 2). 심장 관련 약 외에도 산소함유량을 개 선하고(예: 빈혈 환자의 수혈), 산소 요구량을 줄이는(예: 기관내삽관, 기계환기, 진정) 치료법이 도움이 될 수 있다. 심장성 쇼크가 약물요법에 빠르게 반응하지 않으면, 기계 적 순환보조 장치(mechanical circulatory support, $\mathrm{MCS})$ 를 고려한달).

\section{5) MCS}

$\mathrm{MCS}$ 의 목표는 적절한 전신 관류 유지, 신장 및 간 기능 안정화 및 회복, 심근 부하 감소, 심장성 쇼크 안정화 및 심한 폐부종 환자를 위한 호흡 지원 등이다. 이 목표를 설 명하는 용어로, 'bridge-to-recovery', 'bridge-to-decision', 'bridge-to-bridge' 등이 있다. MCS는 일반적 으로 최대의 약물요법(예: 수축촉진약, 후부하 감소제)에 도 호전되지 않는 쇼크 환자에게 적용하지만, '최대' 의 의 미가 기관 또는 의사의 경험에 따라 다를 수 있어 보편적 


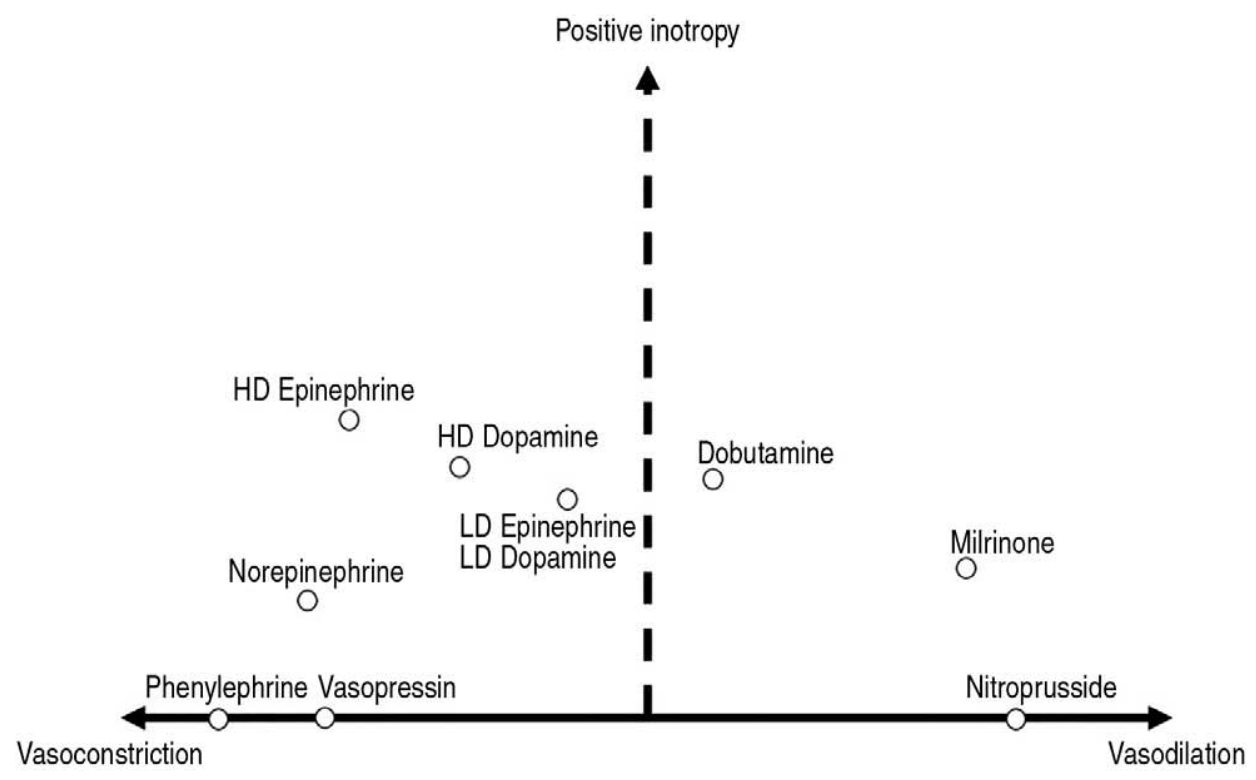

Fig. 1. Vascular responses to vasoactive medications. HD: high dose, LD: low dose.

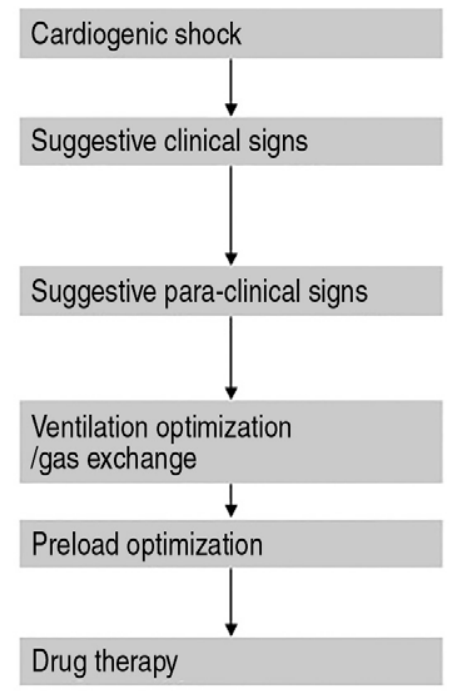

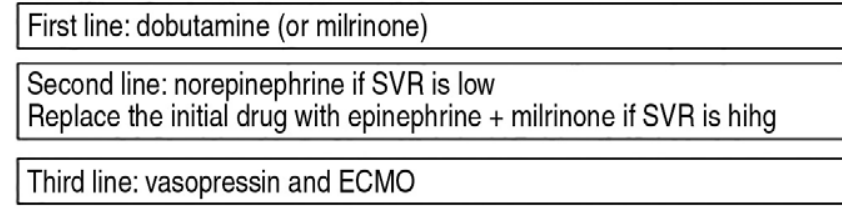

Fig. 2. Cardiogenic shock treatment guidelines. BNP: B-type natriuretic peptide, NT-pro BNP: N-terminal pro-B-type natriuretic peptide, SVR: systemic vascular resistance, ECMO: extracorporeal membrane oxygenation.

적응증을 만들기 어렵다. MCS가 심실 부하 및 산소요구 량에 미치는 유익한 효과 때문에 적극 약물요법에 반응하 지 않는 심장성 쇼크 시, 이 장치를 조기 적용하면 대부분 의 상황에서 더 나은 결과를 얻을 수 있다는 보고가 있다 ${ }^{34)}$. 원활한 $\mathrm{MCS}$ 적용을 위해, 대상자에게 널리 사용하는 Interagency Registry for Mechanically Assisted
Circulatory Support profile로 중증도를 분류할 수 있 다(profile 1이 "critical cardiogenic shock")"

역사적으로 보면, 체외막산소공급(extracorporeal membrane oxygenation, ECMO)은 소아 심장성 쇼크 및 불 응 심부전의 유일한 $\mathrm{MCS}$ 수단이었다. 하지만 소아에서도 $\mathrm{VAD}$ 의 단기 사용이 가능해지면서, $\mathrm{ECMO}$ 는 폐기능 지원 
이 필요한 소아 환자에 주로 시행하고 있다. $\mathrm{ECMO}$ 는 용 적과부하 및 좌심실 확장말기압력 상승으로 인한 폐기능 장애를 동반하는 소아 환자의 심폐기능을 지원할 수 있는 데, 최근 소아 ECMO 이용 방침은 말초 삽입관(cannula) 사용을 병행하며, 순환보조를 더 쉽게 하려고 하는 것이 다. 또한, 소아용 삽입관 개발로 $\mathrm{ECMO}$ 의 다양한 관삽입 (cannulation) 전략이 소아 환자에게 가능해지면서 유연 하게 이용되고 있다. 중심 관삽입 전략은 대동맥 및 우심 방을 이용하며, 대개 심장수술 후, 큰 동맥관개존증 또는 공격적 심실 감압이 필요한 환자에게 사용한다. 이 전략의 장점은 빠른 효과, 높은 정맥 배액, 좌심방 배액과 좌심실 관삽입이 쉬운 점이다. 하지만, 중앙 흥골절개 자체와 출 혈 및 감염 위험이 중심 관삽입의 장애 요인으로 작용할 수 있다. 소아 환자는 말초혈관 크기가 작으므로 경동맥 및 내경정맥을 통한 목 삽입관이 말초 관삽입 전략을 위한 가장 일반적인 방법이다. 그러나, 말초 관삽입은 종종 작 은 삽입관 크기로 인해 전체 흐름을 달성하는 효과가 제한 적일 수 있으며, 치료 기간에 경동맥 원위 폐쇄 가능성이 있어 논란의 여지가 있다 ${ }^{36}$. 연장아에서 대퇴 동맥 및 정맥 이 가장 흔한 말초 관삽입 부위이다. 하지만, 이 혈관이 심 장도관삽입 및 심혈관조영에 반복 사용되는 복잡한 선천 심장병 환자에서는 적용할 수 없는 단점이 있고, 동맥보다 큰 삽입관을 넣은 후 사지 말단의 허혈 위험도 보고된다 ${ }^{377}$.

급성 좌심실 기능장애를 보조하기 위해 veno-arterial $\mathrm{ECMO}$ 를 사용하는 것은 심실 부하를 줄이지 못할 수 있 다. 좌심실 감압이 이뤄지지 않으면 좌심실 압력이 증가한 상태를 유지한다. 심실 부하를 줄임으로써 심근 회복을 꾀 하기 위해, 심부전 또는 전격 심근염 환자에서 좌심실 환 기(left ventricular venting)를 수행할 수 있다라. 좌심 실 환기와 달리, 좌심방 환기(left atrial venting)는 좌 심방 부하를 개선함으로써 폐부종 호전에 더 효과적일 수 있다 ${ }^{34)} \mathrm{ECMO}$ 요법의 시작은 최적의 환기 삽입관 배치라 고 할 수 있다.

삽입관을 배치할 때 지혈에 주의해야 한다. 출혈 시 수 혈하거나 항응고제 용량을 줄이면, 종종 조기 산소공급기 (oxygenator) 기능장애 및 삽입관 혈전증 등 유해한 연 쇄반응을 초래할 수 있다. $\mathrm{ECMO}$ 가 소아에서 단기 $\mathrm{MCS}$ 의 주된 역할을 수행해 왔지만, 최근 $\mathrm{VAD}$ 사용이 증가하 고 있다. 이는 소아에게 적용 가능한 작은 크기의 펌프 발 달, 산소공급기를 사용하지 않는 장점, 항응고제 요법의 발전으로 가능해졌다. 그러므로, 폐부종으로 인한 호흡부 전이 없고 $\mathrm{VAD}$ 의 금기에 해당하지 않는 환자에서 $\mathrm{VAD}$ 는 $\mathrm{ECMO}$ 의 대안이 될 수 있다. 산소공급기 없이 $\mathrm{VAD}$ 에 서 삽입관 배치는 심방 또는 심실에 직접 혈류를 유입해야
하므로 더 제한적인데, 전격 심근염 환자에게는 주로 좌심 방 관삽입을 권장하고, 단기 $\mathrm{VAD}$ 사용에는 주로 원심 펌 프(centrifugal pump)를 사용한다.

심장이식은 말기 심부전의 최종 치료법이다. 그러나, 소 아(특히 체중이 작은)에서 적은 공여자 수와 면역부적합으 로 이식 대기 중 사망률이 높고, 특히 심장성 쇼크가 발생 한 선천심장병 또는 심근염 환자가 더 위험하달.

대표적인 소아 $\mathrm{VAD}$ 는 작은 영아에서도 사용되고 있는 Berlin Heart EXCOR ${ }^{\circledR}$ (Berlin Heart GmbH, Berlin, Germany)이다. 이는 심장이식 전 장기(長期) $\mathrm{VAD}$ 로 사 용되며, 공기압을 이용한 박동성(pulsatile) 심장기능 보 조장치로서 신생아 및 영아 대상으로 유일하게 미국 식품 의약국 허가를 받은 제품이다. $\mathrm{ECMO}$ 보다 합병증이 적 고, 이식 전 재활치료를 통해 전신 상태 호전을 기대할 수 있다.

최근 새롭게 성인 대상으로 개발된 지속형(continuous-flow) VAD는 크기가 작아 소아-청소년 대상으로 사용할 수 있다. 이 장치는 박동성 $\mathrm{VAD}$ 보다 뇌혈관 합병 증 및 기계 이상의 발생률이 낮다고 알려졌다 ${ }^{40,41)}$. 하지만 여전히 성인용 제품을 작은 소아에 적용하기는 어려워, 이 환자군에도 적용 가능한 지속형 $\mathrm{VAD}$ 개발이 기대된다. 2018년, 한국에서도 Berlin Heart EXCOR ${ }^{\circledR}$ 가 건강보험 급여 항목으로 승인되어 일부 병원에서 소아를 대상으로 사용 중이다. 2020 년, 10 개월 확장심근병증 환자가 Berlin Heart $\mathrm{EXCOR}^{\circledR}$ 적용 24일 후 이식에 성공한 첫 한국 증례가 보고됐다 ${ }^{42)}$. 새로운 $\mathrm{VAD}$ 및 삽입관은 약물요 법에 반응하지 않는 심장성 쇼크 환자의 예후 개선에 도움 이 될 것이다.

\section{COVID-19 연관 MIS-C에 의한 심장성 쇼크}

SARS-CoV-2는 안지오텐신전환효소-2 수용체에 결합 하여 세포 안으로 진입하는데, 이 효소는 레닌-안지오텐신알도스테론계의 핵심 요소로, 심혈관질환의 병태생리에 중요한 역할을 한다. 또한, 이 감염에 의한 심혈관질환 악 화는 레닌-안지오텐신-알도스테론계의 조절 장애 및 고 혈압 또는 죽상경화증과 같은 동반 질환에 기인한다 ${ }^{43,44)}$. 인터루킨 $-6,-17$ 및 기타 사이토카인의 방출 조절 장애와 $\mathrm{T}$ 세포 활성화로 인한 사이토카인 폭풍은 COVID-19에서 심혈관질환을 유발할 수 있다. 이러한 면역계 활성화는 죽 상경화판의 불안정을 초래하여 급성 관상동맥질환이 발생 할 수 있다 ${ }^{44,45)}$.

COVID-19 대유행 시대에 열, 위장관 증상, 발진, 쇼크를 보이는 MIS-C 증례가 보고되고 있다 ${ }^{11}$. 진단 기준은 가와 
사키병과 유사하다 ${ }^{46-48)}$. MIS-C 환자의 47\%-80\% 및 $4 \%-29 \%$ 에서 각각 승압제 및 $\mathrm{ECMO}$ 가 필요했다 $11,49-51$. 현재 추정하고 있는 병태생리는, 발생 시점에 환자에서 $\mathrm{SARS}-\mathrm{CoV}-2$ 에 대한 항체가 확인되는 점에서 이 바이 러스에 대한 면역 이상반응이다. 가와사키병에서 알려진 것처럼, MIS-C의 면역복합체가 혈관 및 심근 손상에 관 여하고, 이로 인해 관상동맥 확장 및 심실기능 저하를 유 발하는 것으로 추정하고 있다 ${ }^{52)}$. 대부분 중증 경과를 보이 며, 중환자실 치료, 면역조절, 승압제 및 항응고제 투여가 필요하다. ${ }^{3)}$ 미국, 영국, 프랑스, 스위스의 MIS-C 치료 경 험을 종합한 결과 $(\mathrm{n}=378)$, 사망률은 $1.9 \%$ (7명)였고, 치료법별로 정맥내면역글로불린이 $73.8 \%$ (279명), 스테 로이드가 $53.7 \%$ (203명), 수축촉진약이 $54.5 \%$ (206명) 에서 필요했으며 ${ }^{53)}, \mathrm{ECMO}$ 시행 빈도는 4\%-29\%로 프랑 스에서 가장 높았다 ${ }^{49}$.

\section{결 론}

본 종설에서는 소아 심장성 쇼크의 인지, 진단, 치료 및
감시에 대해 전반적으로 고찰하고, 치료 방침을 제시했다 (Fig. 2). 새롭게 적용되는 $\mathrm{VAD}$ 가 불응 쇼크의 치료에 도 움이 되고 있다. 또한, COVID-19 대유행 시대에 MIS-C 에 의한 심장성 쇼크 발생에 대해 대비해야 한다.

\section{ORCID}

Sungkyu Cho (https://orcid.org/0000-0003-0492-2814)

Sang-Yun Lee (https://orcid.org/0000-0002-3071-2661)

\section{이해관계}

모든 저자는 이 논문과 관련된 이해 관계가 없음.

\section{재정지원}

모든 저자는 이 논문과 관련된 재정지원을 받지 않았음.

\section{References}

1. Mtaweh H, Trakas EV, Su E, Carcillo JA, Aneja RK. Advances in monitoring and management of shock. Pediatr Clin North Am 2013;60:641-54.

2. Brissaud O, Botte A, Cambonie G, Dauger S, de Saint Blanquat L, Durand P, et al. Experts' recommendations for the management of cardiogenic shock in children. Ann Intensive Care 2016;6:14.

3. Kaushik A, Gupta S, Sood M, Sharma S, Verma S. A systematic review of multisystem inflammatory syndrome in children associated with SARS-CoV-2 infection. Pediatr Infect Dis J 2020;39:e340-6.

4. Sperotto F, Friedman KG, Son MBF, VanderPluym CJ, Newburger JW, Dionne A. Cardiac manifestations in SARSCoV-2-associated multisystem inflammatory syndrome in children: a comprehensive review and proposed clinical approach. Eur J Pediatr 2020;15:1-16.

5. Turner DA, Cheifetz IM. Shock. In: Kliegman RM, St. Geme JW, editors. Nelson textbook of pediatrics. 21th ed. Philadelphia (PA): Elsevier Health Sciences; 2020. p. 572.

6. Black RE, Morris SS, Bryce J. Where and why are 10 million children dying every year? Lancet 2003;361:2226-34.

7. Fisher JD, Nelson DG, Beyersdorf H, Satkowiak LJ. Clinical spectrum of shock in the pediatric emergency department. Pediatr Emerg Care 2010;26:622-5.
8. Singh D, Chopra A, Pooni PA, Bhatia RC. A clinical profile of shock in children in Punjab, India. Indian Pediatr 2006; 43:619-23.

9. Rossano JW, Kim JJ, Decker JA, Price JF, Zafar F, Graves DE, et al. Prevalence, morbidity, and mortality of heart failure-related hospitalizations in children in the United States: a population-based study. J Card Fail 2012;18:459-70.

10. Webster G, Zhang J, Rosenthal D. Comparison of the epidemiology and co-morbidities of heart failure in the pediatric and adult populations: a retrospective, cross-sectional study. BMC Cardiovasc Disord 2006;6:23.

11. Whittaker E, Bamford A, Kenny J, Kaforou M, Jones CE, Shah P, et al. Clinical characteristics of 58 children with a pediatric inflammatory multisystem syndrome temporally associated with SARS-CoV-2. JAMA 2020;324:259-69.

12. Jiang L, Tang K, Levin M, Irfan O, Morris SK, Wilson K, et al. COVID-19 and multisystem inflammatory syndrome in children and adolescents. Lancet Infect Dis 2020;20:e276-88.

13. Verdoni L, Mazza A, Gervasoni A, Martelli L, Ruggeri M, Ciuffreda M, et al. An outbreak of severe Kawasaki-like disease at the Italian epicentre of the SARS-CoV-2 epidemic: an observational cohort study. Lancet 2020;395:1771-8.

14. Barber AE, Shires GT. Cell damage after shock. New Horiz 1996;4:161-7. 
15. Cannon JW. Hemorrhagic shock. N Engl J Med 2018;378: 1852-3.

16. Angus DC, van der Poll T. Severe sepsis and septic shock. N Engl J Med 2013;369:2063.

17. Hinshaw LB. Sepsis/septic shock: participation of the microcirculation: an abbreviated review. Crit Care Med 1996;24: 1072-8.

18. Tuchschmidt JA, Mecher CE. Predictors of outcome from critical illness. Shock and cardiopulmonary resuscitation. Crit Care Clin 1994;10:179-95.

19. Kantor PF, Lougheed J, Dancea A, McGillion M, Barbosa $\mathrm{N}$, Chan C, et al. Presentation, diagnosis, and medical management of heart failure in children: Canadian Cardiovascular Society guidelines. Can J Cardiol 2013;29:1535-52.

20. Mendelson J. Emergency department management of pediatric shock. Emerg Med Clin North Am 2018;36:427-40.

21. Nohria A, Tsang SW, Fang JC, Lewis EF, Jarcho JA, Mudge $\mathrm{GH}$, et al. Clinical assessment identifies hemodynamic profiles that predict outcomes in patients admitted with heart failure. J Am Coll Cardiol 2003;41:1797-804.

22. Jones TL, Nakamura K, McCabe JM. Cardiogenic shock: evolving definitions and future directions in management. Open Heart 2019;6:e00960.

23. Overgaard CB, Dzavik V. Inotropes and vasopressors: review of physiology and clinical use in cardiovascular disease. Circulation 2008;118:1047-56.

24. Rossano JW, Shaddy RE. Heart failure in children: etiology and treatment. J Pediatr 2014;165:228-33.

25. Rossano JW. Heart failure. In: Kliegman RM, St. Geme JW, editors. Nelson textbook of pediatrics. 21th ed. Philadelphia (PA): Elsevier Health Sciences; 2020. p. 2476.

26. Biomarkers Definitions Working G. Biomarkers and surrogate endpoints: preferred definitions and conceptual framework. Clin Pharmacol Ther 2001;69:89-95.

27. Dellinger RP, Levy MM, Carlet JM, Bion J, Parker MM, Jaeschke R, et al. Surviving Sepsis Campaign: international guidelines for management of severe sepsis and septic shock: 2008. Intensive Care Med 2008;34:17-60.

28. Hatherill M, McIntyre AG, Wattie M, Murdoch IA. Early hyperlactataemia in critically ill children. Intensive Care Med 2000;26:314-8.

29. Babuin L, Jaffe AS. Troponin: the biomarker of choice for the detection of cardiac injury. CMAJ 2005;173:1191-202.

30. Tervonen V, Arjamaa O, Kokkonen K, Ruskoaho H, Vuolteenaho O. A novel cardiac hormone related to A-, Band C-type natriuretic peptides. Endocrinology 1998;139: 4021-5.

31. Kantor PF, Rusconi P, Lipshultz S, Mital S, Wilkinson JD, Burch M. Current applications and future needs for biomarkers in pediatric cardiomyopathy and heart failure: summary from the second International Conference on Pediatric
Cardiomyopathy. Prog Pediatr Cardiol 2011;32:11-4.

32. Rossano JW, Shaddy RE. Update on pharmacological heart failure therapies in children: do adult medications work in children and if not, why not? Circulation 2014;129:607-12.

33. O'Connor MJ, Rossano JW. Ventricular assist devices in children. Curr Opin Cardiol 2014;29:113-21.

34. Burkhoff D, Sayer G, Doshi D, Uriel N. Hemodynamics of mechanical circulatory support. J Am Coll Cardiol 2015;66: 2663-74.

35. Stevenson LW, Pagani FD, Young JB, Jessup M, Miller L, Kormos RL, et al. INTERMACS profiles of advanced heart failure: the current picture. J Heart Lung Transplant 2009;28: 535-41.

36. Teele SA, Salvin JW, Barrett CS, Rycus PT, Fynn-Thompson F, Laussen PC, et al. The association of carotid artery cannulation and neurologic injury in pediatric patients supported with venoarterial extracorporeal membrane oxygenation. Pediatr Crit Care Med 2014;15:355-61.

37. Gander JW, Fisher JC, Reichstein AR, Gross ER, Aspelund $\mathrm{G}$, Middlesworth W, et al. Limb ischemia after common femoral artery cannulation for venoarterial extracorporeal membrane oxygenation: an unresolved problem. J Pediatr Surg 2010;45:2136-40.

38. Hacking DF, Best D, d'Udekem Y, Brizard CP, Konstantinov IE, Millar J, et al. Elective decompression of the left ventricle in pediatric patients may reduce the duration of venoarterial extracorporeal membrane oxygenation. Artif Organs 2015; 39:319-26.

39. Jatene MB, Miana LA, Pessoa AJ, Riso A, Azeka E, Tanamati $\mathrm{C}$, et al. Pediatric heart transplantation in refractory cardiogenic shock: a critical analysis of feasibility, applicability and results. Arq Bras Cardiol 2008;90:329-33.

40. Miera O, Potapov EV, Redlin M, Stepanenko A, Berger F, Hetzer R, et al. First experiences with the HeartWare ventricular assist system in children. Ann Thorac Surg 2011; 91:1256-60.

41. Blume ED, Rosenthal DN, Rossano JW, Baldwin JT, Eghtesady P, Morales DL, et al. Outcomes of children implanted with ventricular assist devices in the United States: first analysis of the Pediatric Interagency Registry for Mechanical Circulatory Support (PediMACS). J Heart Lung Transplant 2016;35:578-84.

42. Shin JH, Park HK, Jung SY, Kim AY, Jung JW, Shin YR. The first pediatric heart transplantation bridged by a durable left ventricular assist device in Korea. Korean J Thorac Cardiovasc Surg 2020;53:79-81.

43. Fulchand S. Covid-19 and cardiovascular disease. BMJ 2020;369:m1997.

44. European Society of Cardiology (ESC). ESC guidance for the diagnosis and management of $\mathrm{CV}$ disease during the COVID-19 pandemic [Internet]. Sophia Antipolis, FR: ESC; 
2020 [cited 2020 Jun 10]. Available from: https://www.escardio.org/Education/COVID-19-and-Cardiology/ESC-COVID19-Guidance.

45. Guo T, Fan Y, Chen M, Wu X, Zhang L, He T, et al. Cardiovascular implications of fatal outcomes of patients with coronavirus disease 2019 (COVID-19). JAMA Cardiol 2020;5:811-8.

45. World Health Organization (WHO). Multisystem inflammatory syndrome in children and adolescents temporally related to COVID-19 [Internet]. Geneva: WHO; 2020 [cited 2020 May 15]. Available from: https://www.who.int/news-room/commentaries/detail/multisystem-inflammatory-syndrome-inchildren-and-adolescents-with-covid-19.

47. Health Policy team of Royal College of Paediatrics and Child Health (RCPCH). Paediatric multisystem inflammatory syndrome temporally associated with COVID-19 (PIMS) - guidance for clinicians [Internet]. London: RCPCH; 2020 [cited 2020 May 1]. Available from: https://www.rcpch.ac.uk/ resources/guidance-paediatric-multisystem-inflammatorysyndrome-temporally-associated-covid-19-pims.

48. Centers for Disease Control and Prevention (CDC). Emergency preparedness and response: HAN00432 [Internet]. Atlanta (GA): CDC; 2020 [cited 2020 May 14]. Available from: https://emergency.cdc.gov/han/2020/han00432.asp.

49. Belhadjer Z, Méot M, Bajolle F, Khraiche D, Legendre A, Abakka S, et al. Acute heart failure in multisystem inflammatory syndrome in children in the context of global SARS-CoV2 pandemic. Circulation 2020;142:429-36.

50. Dufort EM, Koumans EH, Chow EJ, Rosenthal EM, Muse A, Rowlands J, et al. Multisystem inflammatory syndrome in children in New York State. N Engl J Med 2020;383:347-58.

51. Feldstein LR, Rose EB, Horwitz SM, Collins JP, Newhams $\mathrm{MM}$, Son MB, et al. Multisystem inflammatory syndrome in U.S. children and adolescents. N Engl J Med 2020;383:334-46.

52. Menikou S, Langford PR, Levin M. Kawasaki disease: the role of immune complexes revisited. Front Immunol 2019; 10:1156.

53. Elias MD, McCrindle BW, Larios G, Choueiter NF, Dahdah $\mathrm{N}$, Harahsheh AS, et al. Management of multisystem inflammatory syndrome in children associated with COVID-19: a survey from the International Kawasaki Disease Registry. CJC Open 2020;2:632-40. 